MAX MARMOR

\section{Art History and the Digital Humanities}

In his thoughtful - and thought-provoking - invitation to this very welcome "debate" about "Art History and the Digital Humanities," Hubertus Kohle reminds us that art history has played, at best, a supporting role in the myriad efforts to institutionalize the emerging digital humanities. The irony of the fact that a few lone art historical visionaries anticipated the field of digital art history decades ago is not lost upon Professor Kohle. And one can argue that the duo of art historians he cites were indeed among the John the Baptists of digital art history, prophetic "voices crying in the wilderness."

In this brief response to Professor Kohle's characteristically stimulating essay, I wish to sound a more encouraging note. It may be true that art history has not played a leading role in the emergence of the digital humanities. As Kohle acknowledges, he is not the first to lament this fact, citing James Cuno's provocative 2012 essay How Art History is Failing at the Internet. ${ }^{2}$ I would add that Diane Zorich had previously reached a similarly melancholy conclusion in her thoughtful study, Transitioning to a Digital World: Art History, Its Research Centers, and Digital Scholarship, which I would commend to readers of this "debate." 3 Yet the past few years have seen a growing interest in digital art history. While it would be premature to assert that the tide of digital art history has definitively turned - art history is, after all, a field perfectly capable of institutional regression! - I believe there are encouraging signs on the horizon. ${ }^{4}$

In response to art history's failure to engage adequately with the digital humanities, Professor Kohle describes eight promising arenas in which the innovative potential of the digital humanities could significantly enrich the study and teaching of the history of art as well art historical research and scholarship. Those eight fronts are: (1) the application of quantitative methods to art historical problems; (2) the discovery of art historical correlations that human intelligence cannot easily identify, but which only human intelligence can confirm; (3) the employment of large image databases to contextualize canonic works of art by situating them within a potentially encyclopedic corpus of images of world art; (4) the ability technology provides to examine images of art works more closely than the unaided human eye can do, opening the prospect of studying "historicity on the level of the pixel"; (5) crowdsourcing and realigning the relationship between expert and layman by defining a new and productive role for the latter; (6) the growing array of professional options for teaching on the Internet, expanding educational opportunities and impacts while also opening the door to new models of university-based research; (7) new avenues for art historical publication (if we can overcome the barriers posed by traditional approaches to intellectual property); (8) digitization in museums, which surely must become an integral and ultimately routine by-product of object cataloging. 
Space does not permit me to invoke more than a few of the recent developments that feed my optimism about the fortunes of digital art history. So let me simply point the interested reader to a very few, representative projects that I believe demonstrate an emerging engagement with the eight extremely promising developments Professor Kohle cites. I will focus here upon projects that touch on multiple, complementary and sometimes overlapping approaches.

Professor Kohle cites Lutz Heusinger's pioneering work at Foto Marburg as among the precursors of digital art history, and it is, I think, no accident that some of the most exciting and promising digital art history initiatives involve traditional photographic archives. The recent announcement that a consortium of key European and North American photo archives (PHAROS) intends to digitize their combined holdings, resulting in an aggregated database of perhaps 31 million art images, ${ }^{5}$ will surely open the door to truly innovative projects with profound implications for art historical studies. As an especially promising example of the great potential of digital projects based in photographic archives, I would cite the pioneering work in computer visualization now being undertaken by John Resig, Dean of Computer Science at the Internetbased Khan Academy, working with thousands of photographic images of anonymous Italian paintings in the context of an exemplary partnership between the Frick Art Reference Library and the Fototeca at the Fondazione Zeri in Bologna. ${ }^{6}$ This project exemplifies the first two of the new approaches for which Professor Kohle advocates: (1) the application of quantitative methods to art historical problems and (2) the discovery of visual correlations that human intelligence cannot easily identify, but which only human intelligence can verify. By virtue of its very scale, the PHAROS partnership, should it come to even partial fruition, further promises to address Kohle's third theme: situating canonic works of art within a potentially encyclopedic corpus of images of world art. A kindred, if much more focused effort, Harvard University's recent digitization of Bernard Berenson's corpus of roughly 11,000 photographs at the Villa I Tatti devoted to "Homeless Paintings of the Italian Renaissance," promises to offer an exciting experiment in judicious crowdsourcing (the fifth of Professor Kohle's promising new approaches to digital art history). ${ }^{\text {? }}$

New models of teaching art history on the Internet (Professor Kohle's sixth new direction) are also emerging in exciting ways. I would single out Smarthistory, ${ }^{8}$ the shared vision of two art historians with roots in academe and art museums who have enlisted a cohort of teachers and scholars at all levels of professional accomplishment to create an expanding corpus of online videos on the history of world art. A key aspect of these videos is that they are dialogical in nature, intentionally departing from the traditional single "authoritarian voice" of the lec- 
turer in favor of an open-ended, exploratory dialogue about works of art, monuments and sites. Widely adopted by teachers of art history, Smarthistory promises to enable and encourage what Professor Kohle describes as a "shift" in the "role of the university to an even more collaborative examination of research material."

The subject of new approaches to publishing in art history (Kohle's seventh topic) was explored precisely a decade ago by Mariët Westermann and Hilary Ballon in their Mellon-sponsored study, Art History and its Publications in the Electronic Age (2006). ${ }^{9}$ That study identified many of the challenges facing online publishing in art history - challenges which, as Professor Kohle rightly laments, still constitute significant barriers. These include, above all, the abiding "virulent copyright issues" (Kohle) that confront online publishing (and not only online publishing) in art history. These issues, of course, are rooted - turning to Professor Kohle's eighth and final theme - in a deeply conservative traditional museum culture. That culture seeks to control the circulation of images of art works, reflecting both a curatorial concern about accuracy and authenticity and an economic interest in leveraging the management of rights and reproductions for the sake of museum revenues. Fortunately, that facet of museum culture is beginning to change, with an expanding, international array of distinguished academic and municipal art museums now sharing high resolution images of their public domain collections on an "open access" basis online. Another encouraging development is the recent release on the part of the College Art Association, the principle professional body of North American academic art historians and artists, of an ambitious "fair use code" for the visual arts. ${ }^{10}$ While "fair use" exceptions to copyright are specific to U.S. copyright legislation, we may hope that similar provisions for the educational, non-commercial use of digital images of art works will be adopted internationally in the foreseeable future.

1 Kohle cites William Vaughan (Birkbeck College, University of London) and Lutz Heusinger (Foto Marburg) in this context. Another noteworthy prophet of digital art history is Jules Prown, Professor Emeritus of Art History at Yale University. See Jules Prown, The Art Historian and the Computer: An Analysis of Copley's Patronage, 1753 - 74, in: Smithsonian Journal of History 1, 1966, 17 - 30. On Prown see quite recently Pamela Fletcher, Reflections on Digital Art History, in: caa.Reviews, 18 June 2015, URL: http://www.caareviews.org/reviews/2726\#. VxkBjvkrJD8 (date of last access 6 May 2016), and Matthew Lincoln in: Johanna Drucker, Anne Helmreich, Matthew Lincoln, and Francesca Rose, Digital Art History: the American Scene, in: Perspective: actualité en histoire de l'art 2, 2015, URL: http://perspective.revues.org/6021 (date of last access 6 May 2016). On the prehistory of digital art history in general, see now especially Benjamin Zweig, Forgotten Genealogies: Brief Reflections on the History of Digital Art History, in: International Journal of Digital Art History 1, 2015, URL: https://journals.ub.uniheidelberg.de/index.php/dah/article/view/21633 (date of last access 6 May 2016). 
2 James Cuno, How Art History is Failing at the Internet, in: The Daily Dot, 19 November 2012, URL: http://www.dailydot.com/opinion/art-history-failinginternet/ (date of last access 6 May 2016).

3 Diane Zorich, Transitioning to a Digital World: Art History, Its Research Centers, and Digital Scholarship, URL: http://www.kressfoundation.org/uploadedFiles/Sponsored_Research/Research/Zorich_TransitioningDigitalWorld.pdf (date of last access 6 May 2016). This study was sponsored by the Samuel H. Kress Foundation and the Roy Rosenzweig Center for History and New Media at George Mason University.

4 A similarly optimistic conclusion is reached in a 2014 study, sponsored by the Getty and Kress Foundations. See Roger C. Schonfeld and Matthew P. Long, Supporting the Changing Research Practices of Art Historians, 30 April 2015, URL: http://www.sr.ithaka.org/publications/supporting-the-changingresearch-practices-of-art-historians/ (date of last access 6 May 2016), and more recently Drucker, Helmreich, Lincoln, and Rose 2015 (as note 1).

5 Ellen Prokop, The Future of Photoarchives, URL: http://www.frick.org/photoarchive/discoveries/future_photoarchives (date of last access 6 May 2016). A prototype of PHAROS may be found at http://images.pharosartresearch.org/ (date of last access 29 June 2016).

6 Louisa Wood Ruby, Kress Foundation Grant for Image Analysis Toolkit, URL: http://www.frick.org/photoarchive/discoveries/kress_foundation_grant_for_ image_analysis_toolkit (date of last access 6 May 2016).

7 Berenson Library, Villa I Tatti, Harvard Center for Italian Renaissance Studies, Homeless Paintings of the Italian Renaissance. How Do We Know About, and How Do We Study, Works of Art That Have Disappeared From View?, URL: http://itatti.harvard.edu/berenson-library/collections/fototeca-photographarchive/homeless-paintings-italian-rena (date of last access 6 May 2016).

8 See the website of Smarthistory, URL: http://smarthistory.org/ (date of last access 6 May 2016). Beth Harris and Steven Zucker started Smarthistory in 2005 to create content for their students. Smarthistory launched its first custom-designed website in 2007 with the support of the Samuel H. Kress Foundation. Since then, Smarthistory has won numerous awards and its audience of undergraduate and graduate students, high school students, instructors, and informal learners has grown significantly. From 2011 -2015, Smarthistory was supported by Khan Academy, URL: https://www.khanacademy.org/humanities/art-history-basics/beginners-art-history/a/cave-painting-contemporaryart-and-everything-in-between (date of last access 6 May 2016). Smarthistory is now an independent not-for-profit, and remains committed to distributing the highest-quality art history content on multiple platforms, including Smarthistory.org, Khan Academy, YouTube, and Flickr.

9 Mariët Westermann and Hilary Ballon, Art History and its Publications in the Electronic Age, 2006, URL: https://www.free-ebooks.net/ebook/Art-Historyand-Its-Publications-in-the-Electronic-Age (date of last access 6 May 2016), a study sponsored by the Andrew W. Mellon Foundation.

10 Code of Best Practices in Fair Use for the Visual Arts, ed. by the College Art Association, February 2015, URL: http://www.collegeart.org/fair-use/ (date of last access 6 May 2016). 